
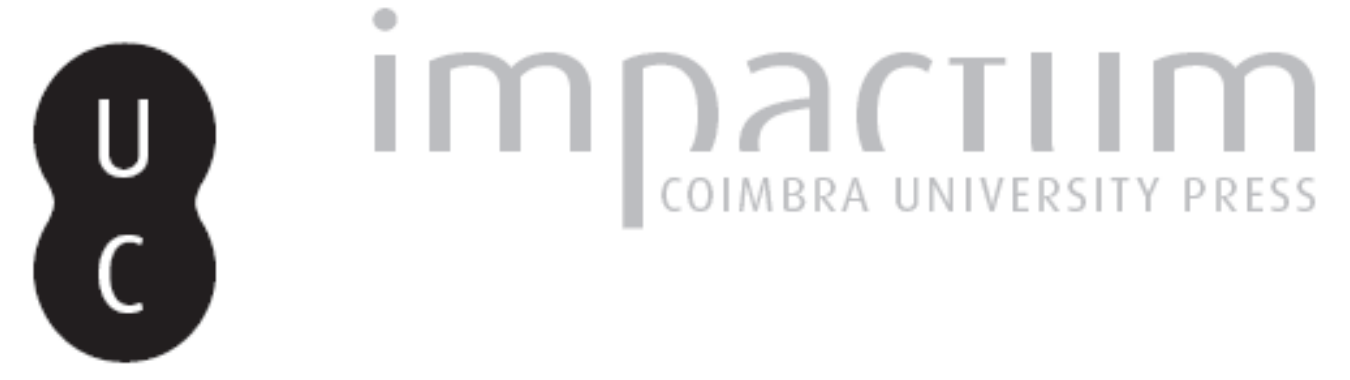

\title{
Models in Plato's Sophist and Statesman
}

\author{
Autor(es): $\quad$ Gill, Mary Louise
}

Publicado por: Imprensa da Universidade de Coimbra

URL persistente:

URI:http://hdl.handle.net/10316.2/42225

DOI:

DOl:https://doi.org/10.14195/2183-4105_6_2

Accessed : $\quad$ 26-Apr-2023 00:20:53

A navegação consulta e descarregamento dos títulos inseridos nas Bibliotecas Digitais UC Digitalis, UC Pombalina e UC Impactum, pressupõem a aceitação plena e sem reservas dos Termos e Condições de Uso destas Bibliotecas Digitais, disponíveis em https://digitalis.uc.pt/pt-pt/termos.

Conforme exposto nos referidos Termos e Condições de Uso, o descarregamento de títulos de acesso restrito requer uma licença válida de autorização devendo o utilizador aceder ao(s) documento(s) a partir de um endereço de IP da instituição detentora da supramencionada licença.

Ao utilizador é apenas permitido o descarregamento para uso pessoal, pelo que o emprego do(s) título(s) descarregado(s) para outro fim, designadamente comercial, carece de autorização do respetivo autor ou editor da obra.

Na medida em que todas as obras da UC Digitalis se encontram protegidas pelo Código do Direito de Autor e Direitos Conexos e demais legislação aplicável, toda a cópia, parcial ou total, deste documento, nos casos em que é legalmente admitida, deverá conter ou fazer-se acompanhar por este aviso.

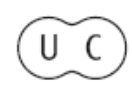




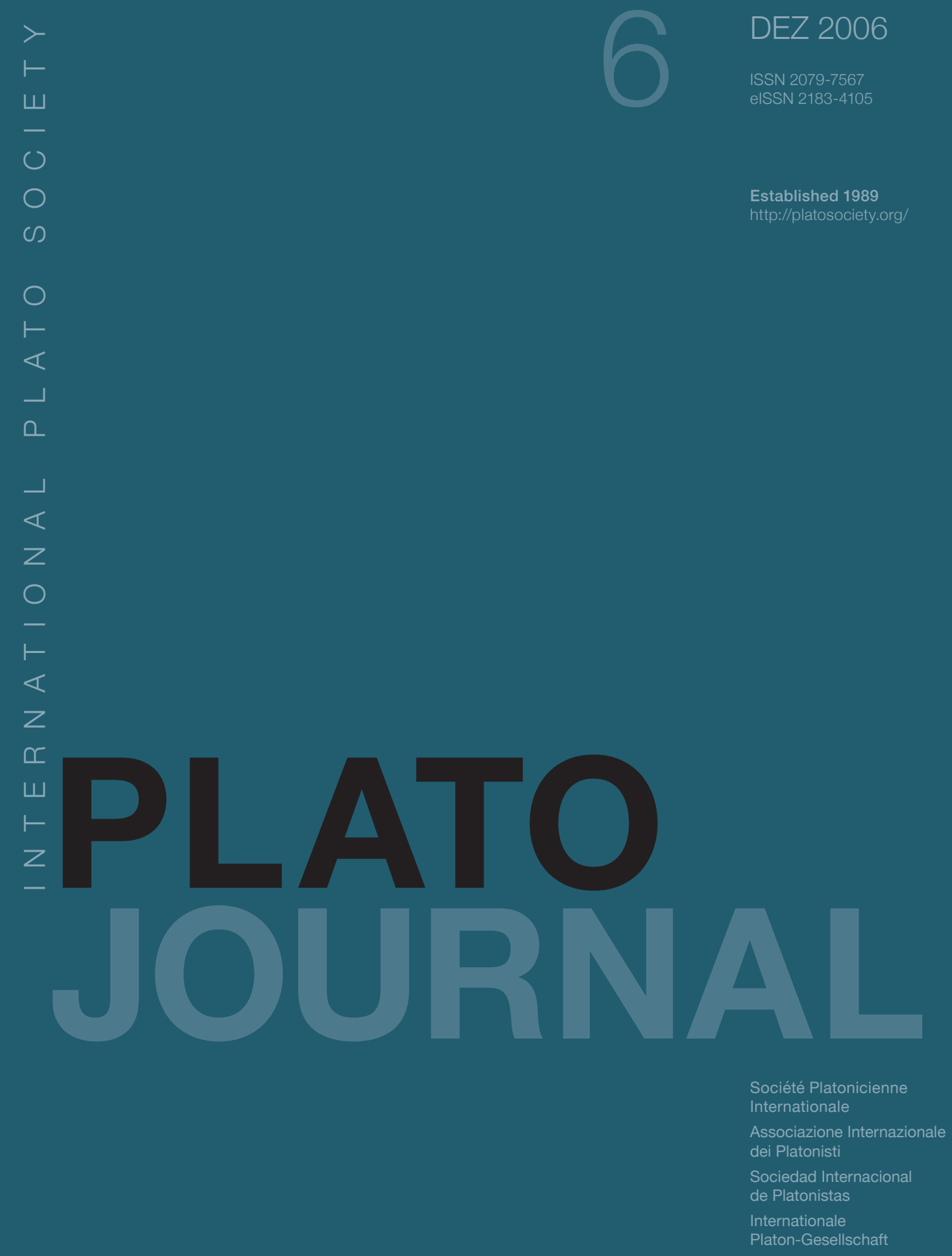




\section{Models In Plato’s Sophist AND STATESMAN}

Plato's Sophist and Statesman use a notion of a model (paradeigma) quite different from the one with which we are familiar from dialogues like the Phaedo, Parmenides, and Timaeus. In those dialogues a paradeigma is a separate Form, an abstract perfect particular, whose nature is exhausted by its own character. Its participants are conceived as likenesses or images of it: they share with the Form the same character, but they also fall short of it because they exemplify not only that character but also its opposite. Mundane beautiful objects are plagued by various sorts of relativity-Helen is beautiful compared to other women, but not beautiful compared to a goddess; she is beautiful in her physical appearance, but not in her soul or her actions; she is beautiful in your eyes, but not in mine, and so on. The Form of the Beautiful, which is supposed to explain her beauty, is simply and unqualifiedly beautiful (Symp. 210e5-211d1).

In the Sophist and Statesman a model involves a mundane example whose definition is relevant to the definition of some more difficult concept under investigation, the target. The steps taken to define the example also reveal a useful procedure to be transferred to the more difficult case. This much should be fairly uncontroversial. In my view it is important to recognize that a paradeigma is not merely an example (or paradigmatic example) of some general concept. ${ }^{1}$ That is to focus on the content of the paradeigma - for instance, on angling as a sort of hunting (which is relevant to the sophist), or on weaving as a sort of intertwining (which is relevant to the statesman). Content matters, but the definition of the example also displays a particular structure discovered by a certain procedure, which is to be transferred to the more difficult case. Like a model house or model housing project, which shows on a small scale how the parts of a house fit together or how a house fits into a community, Plato's paradeigmata reveal the structure of the target or its place within some larger structure. But unlike a model house or housing project, which is useful in building actual houses or communities, Plato's models reveal how the conceptual components of the target should fit together or how the target itself is related to other objects. Those structural features shape its definition. I will use the word "example" when the issue is the similar content of the model and the target. I will speak instead of a "model," when an example is used to reveal a procedure and a content-neutral structure to be looked for in the target.

Models are introduced at various stages of an investigation, typically at the outset or when the investigation has stalled, and they show how to continue the inquiry. ${ }^{2}$ For this

\footnotetext{
${ }^{1}$ I differ from Lane (1998, esp. 61-70), who construes paradeigma in the Statesman simply as example-a special case that reveals a common element shared with the target. Rosen $(1995,81-88)$ has a helpful discussion of the distinction between models and examples, though I disagree with his view (85) that there is only one model for the true account of statecraft. This disagreement reflects a difference between our conceptions of models in the two dialogues.

2 Dimitri El Murr (2006) calls attention to a difficulty, which the Sophist and Statesman do not explicitly address: How do the investigators choose an adequate model without knowing the target in advance? Some scholars have thought that Plato still relies on the doctrine of recollection familiar from the Meno and Phaedo (they cite Stm. 277d1-7, quoted below §3). If the inquirers already have some vague conception of the target, because their souls have previously experienced it when disembodied, that conception would enable them to choose an appropriate model, which would help them fully recollect the target. I agree with El Murr and Kato (1995) that the Statesman does not rely on the doctrine of recollection. I differ from El Murr, however, in
} 
reason, different models, which reveal different features of the target or procedures for its discovery, can apply to a single target. Each model falls short of the target. I will argue that the inquirers need to recognize, not only the feature that is the same in the example and the target, but also the difference between the two embodiments and the procedural difference those different embodiments entail.

Before we turn to our main theme, let us consider our two dialogues in their wider dramatic context.

\section{The Dramatic Context}

The Sophist and the Statesman are the first and second of three dialogues projected to take place the day after Socrates' inconclusive investigation of knowledge with the young mathematician Theaetetus in the eponymous dialogue. After Theaetetus' final attempt to define knowledge fails, the group of speakers-Socrates, Theaetetus, and Theodorus - agree to reconvene the next day. According to Plato's drama, Socrates' immediate destination after the conversation that same day was the King's Porch to face Meletus' indictment for impiety and corrupting the youth. Some scholars regard this dramatic detail as crucial for understanding the Sophist and Statesman: Socrates' unjust indictment and trial are supposed to be the backdrop for the conversations in those works. ${ }^{3}$ This background may be significant, but I think the dramatic detail is important for a different reason. Plato is reminding his readers of what happened that day at the King's Porch. Socrates ran into Euthyphro and struck up a conversation about piety. In the course of that conversation much was said about the requirements for a good definition. Especially important was the claim that a good definition should do more than capture all and only instances that fall under a kind: a good definition should explain why the instances are instances of that kind (esp. Euth. 6d9-e2, 10a1-11b5). Reflection on definition is evidently important to the Theaetetus, since the youth has just failed to give an adequate definition of knowledge. Dramatic details are never gratuitous in Plato. ${ }^{4}$ In my view the allusion to the Euthyphro at the end of the Theaetetus is meant to prompt us, Plato's audience, to reflect on Theaetetus' quandary. ${ }^{5}$ One lesson of the Theaetetus is that we ought to think more seriously about definition and method, and these are main topics of the subsequent dialogues, Sophist and Statesman.

thinking that there is a good deal of trial and error in the Sophist and Statesman. The model of the angler in the Sophist is helpful in introducing the method of dichotomous division, but the example misleads the inquirers about the essence of the sophist (see below §4). The model of weaving in the Statesman is better, but it is introduced much later in the investigation after the initial attempt to define the statesman by dichotomous division has failed. Reflection on the shortcomings of that initial attempt enables the investigators to select a useful model. For more on this topic, see Gill (forthcoming).

3 See Miller (1980), 1-3, 85-86; cf. Rosen (1983), 23 and n.11.

4 Though obviously they can be construed in quite different ways. My own thinking about this topic is indebted to Burnyeat (1997), who argues that we should interpret the dramatic details in light of a dialogue's philosophical content, not vice versa.

${ }^{5}$ Cf. Sayre (1992), 229. Sayre thinks we should be looking for senses of logos other than the three considered in the final part of the Theaetetus. He may be right about this, but I think we should also be reflecting on the three definitions of knowledge Theaetetus has given-perception, true judgment, and an account together with true judgment. Although Socrates says that none of the alternatives separately will do (210a9-b2), we should ask ourselves whether those components might be somehow combined to yield an adequate definition. See below $\S 3$ and Gill (2003a). 
The Sophist opens with Theodorus' acknowledgement that they are meeting according to yesterday's agreement. He has brought with him a visitor from Elea, an associate of Parmenides and Zeno, who is described as a keen philosopher. Mention of the guest as a philosopher initiates the main discussion of the Sophist. What is a genuine philosopher? Sometimes philosophers look like statesmen, sometimes like sophists, and sometimes they seem completely mad $(216 \mathrm{c} 8-\mathrm{d} 2)$. Socrates wants the visitor to tell them what people where he comes from mean by the terms "sophist," "statesman," and "philosopher." Are they three names for one kind, or are there two or three distinct kinds, one for each name? Three kinds, says the Stranger, but it is not easy to distinguish them $(217 \mathrm{~b} 1-4)$. The task undertaken, then, is to define each of the three kinds.

The Eleatic visitor tackles the sophist first. Then, at the beginning of the Statesman, he reminds us that he has two more topics, the statesman and the philosopher, and he chooses to investigate the statesman next. The third member of the trilogy, the Philosopher, is repeatedly promised but appears never to have been written. ${ }^{6}$ I think Plato aroused our expectations and left the dialogue unwritten on purpose to encourage us to do what Theaetetus should be stimulated to do at the end of the Theaetetus: take the various different threads from the preceding discussion and tools that have been provided and figure out how to combine and use them to construct an adequate definition. Theaetetus' task was to define knowledge in general; our task is to define the philosopher and his special expertise. $^{7}$

This paper will focus on one sort of tool Plato uses in the Sophist and Statesman - a model (paradeigma) - and examine in particular a passage in which he gives us a model of a model (Stm. 277d1-278d6). Let us begin by observing three main models in the Sophist and Statesman, two useful to the investigation, a third useful only in exemplifying an inadequate model.

\section{Models}

A good model consists of a trivial example, which is perceptible and can be easily pictured. The instructor uses the example to teach a method of inquiry, which is to be extended to some harder case. Because the example is depictable, the instructor can appeal to visual aids, if the student has trouble following the verbal account. The inquirers practice giving and receiving an account using the example, and then apply the method to a more difficult case, which cannot be pictured and so can only be understood by verbal means (Stm. 285d9-286b1).

The Stranger introduces the investigation of the sophist with the model of an angler. The angler displays in a straightforward way the method of dichotomous divisiondivision of a kind into two sub-kinds - to be used in the upcoming discussion. An angler has a humble profession, which everyone recognizes (Soph. 218e2-5). He engages in a single observable activity: fishing with a special sort of hook. The Stranger arrives at his

\footnotetext{
${ }^{6}$ For the promises, see Soph. 216c2-217b4, with 218b6-c1; 253b9-254b6; Stm. 257a1-c2, with 258b2-3. The title "Philosopher" does not appear on surviving ancient lists of Plato's writings. Since we seem to have all of Plato's published works (plus spuria), the Philosopher was probably never written.

7 As Kenneth Sayre stresses in his forthcoming book on the Statesman (2007), we are told that the point of the exercise in the Statesman is to make us better dialecticians quite generally. See esp. Stm. 285c8-d4.
} 
definition of the angler by first locating his activity in a wide kind, art or expertise $($ techne $) .{ }^{8}$ He then divides art into two subordinate kinds, productive and acquisitive, then continues to divide the acquisitive branch until he reaches his goal. The method of division that yields the definition of angling exemplifies the proper method to use in defining other kinds; and the definition of angling, which results from that division, displays the definitional structure to look for in the harder case. In addition, the example itself proves useful to the upcoming investigation. The division that leads to the first definition of the sophist - a hired hunter of rich young men - matches that of the angler down to hunting, after which the branches diverge, since the sophist hunts creatures that live on dry land, whereas the angler hunts creatures that inhabit the water.

The Statesman first mentions models at a quite different stage of the inquiry, after the visitor and his interlocutor Young Socrates have defined the statesman as a herdsman who rears a human flock. The word "paradeigma" is first used in the dialogue, when the Stranger looks back to that initial division: he speaks of the paradeigma of shepherds and cowherds (275b4-5). Various sorts of herdsmen were mentioned, but they were merely examples that displayed a common character shared with the statesman, that of rearing animals in herds. The herdsman was not a model as I have defined it. ${ }^{9}$ There are many problems with the initial definition, ${ }^{10}$ but one of the more obvious problems is that, for all its complexity, the definition is too general, failing to differentiate the statesman from others who also claim to rear the human flock - the merchants, the farmers, the millers, the physical trainers, the doctors, and many others (267e1-268a4). The guest first attempts to address the shortcoming by telling an elaborate story about two alternating phases of the universe, ${ }^{11}$ one controlled by a god (the age of Cronus), the other left on its own to be governed by human statesmen (the age of Zeus). The visitor later refers to the story as a large-scale model (paradeigma) and compares it to a portrait: it seems adequate in its superficial outline, but lacks sufficient clarity (277b1-c6).

The myth corrects one point in the previous division. Whereas the divine herdsman tends to all human needs, and can therefore be said to "rear" the human flock (274e9275a3), human statesmen tend to only some human needs, while other experts (the farmers, doctors, and so on) tend to others. So the appropriate word that applies to all of them is more general: "care for" rather than "rear." But use of a more general word leaves open the main question: what is the manner of the statesman's care (275a3-6)? How does

\footnotetext{
${ }^{8}$ The divisions in the Sophist and Statesman are divisions of arts (angling, sophistry, weaving, statecraft), and only secondarily of experts who possess those arts. The art is what makes the expert the sort of expert he is. In addition to the problem of choosing an adequate model (see n. 2 above), there is a problem of choosing an appropriate wide kind to divide. At least two considerations are relevant: First, what does the name itself suggest? E.g. the name sophistēs ("sophist") is related to the word sophos ("wise man") and so suggests expertise (technē): see Soph. 221c6-d6; cf. 268b11-c4. Second, what features are shared by items called by that name? Reflection on those common features can indicate an appropriate wide kind to divide.

${ }^{9}$ The association of the statesman with a herdsman was probably conventional, relying on the Homeric epithet of Agamemnon as shepherd of the people (e.g., Il. 2.243, 254 [poimen lā̄n]). For discussion, see Miller (1980), 40.

${ }^{10}$ For a detailed critique, see Dorter (1994), 181-95. For my assessment of the main problems, see Gill (forthcoming), summarized in Gill (2005).

${ }^{11}$ On Rowe's (1995a, 11-13) version there are three periods, but this difference does not affect my argument.
} 
his care for humankind differ from that of the farmers, doctors, and so on? Not only does the myth fail to characterize the manner of the statesman's care, it also fails to indicate how to go on, what procedure might help to isolate our target. That deficiency prompts the Stranger to discuss models and how they are supposed to operate, in a passage to which we shall shortly return. But first let us look at the helpful model of weaving, which does show how to mark off the statesman from others who claim the same expertise.

The Stranger quickly presents a dichotomous division that yields the art of weaving, defined as the art of clothes-working (279c7-280a6). Like the definition of the statesman reached in the first part of the dialogue, this definition suffers from being too general, since many arts compete for the same title: carding, spinning, spindle-making, darning, clothes-cleaning, and others. The main function of the model of weaving is to show how to mark off the art to be defined from others akin to it, all of which are located in the lowest kind reached by the earlier dichotomous division. The guest characterizes the new sort of division as division kata mele, "by limbs, like a sacrificial animal" (287c3-5). ${ }^{12}$ Whereas dichotomous division separates by halves, and then ignores at each step the branch that does not lead to the goal, division by limbs breaks off pieces of an original whole, all of whose members share the same field of operation, and isolates the target from other arts that compete for the same title. The Stranger discusses each rival art to at least the extent that weaving can be defined in relation to it. Many of the rival arts turn out to contribute to weaving by providing its tools or preparing its materials (the sunaitiai or "helping causes"). Some subordinate arts are more akin to it than others. For instance, the art of wool-working is divided (dichotomously) into arts that separate and those that combine. Whereas carding is one of the arts that separate the wool (282b10-c3), both spinning and weaving combine it. But spinning twists the wool into the threads that will constitute the warp and weft, whereas weaving uses the products of spinning and intertwines the two (282c11-283a8).

The differentiation of weaving from various subsidiary arts reveals a new procedure to isolate statecraft from its subsidiary arts. Statecraft will be distinguished from other arts that care for humans in cities. Furthermore, like the model of angling, weaving is relevant not only in indicating a correct procedure that yields a definition with certain structural features, but also as an example. The essence of weaving itself - intertwining of different kinds of threads - proves to be an essential feature of statecraft as well. One of the statesman's main tasks, we learn later, is to weave together the opposed virtues of courage and moderation in his subjects. He is also said to care for all aspects of the city and to weave everything together in the most correct way.

The inadequacy of the Myth of Cronus as a model prompts the Stranger to discuss models as such before introducing the model of weaving. He tells us we need a model of a model.

\footnotetext{
${ }^{12}$ I am grateful to Dimitri El Murr and David Charles for stimulating me to think more carefully about the nature of this sort of division. For my further thoughts on how it differs from dichotomous division, see Gill (forthcoming).
} 


\section{Model of a Model}

With some minor omissions of Young Socrates' replies, I translate the passage as follows (277d1-278d6):

277D

Stranger: It is difficult, my dear friend, adequately to show any of the more important things without using models (paradeigmata). Each of us seems to know everything as in a dream, and then again to be ignorant of everything when as it were awake.

Young Socrates: What do you mean?

Stranger: I do now seem very oddly to have stirred up in us our experience of knowledge. ${ }^{13}$

Young Socrates: How is that? a model.

Stranger: Even the model itself (to paradeigma auto) requires in its turn

Young Socrates: How so? Tell me—don't hesitate on my account.

Stranger: I must tell you, since you are ready to follow. I suppose we know (1) that children, when they have just become acquainted with letters..., adequately discriminate each of the letters in the shortest and easiest syllables (tōn sullabōn), and become able to declare the truth about them... But then again they make mistakes about those same letters in other syllables, and are mistaken both in judgment and speech.

Young Socrates: Of course.

Stranger: Well, then, isn't this the easiest and finest way of leading them to the things that aren't yet recognized?

Young Socrates: How?

Stranger: (2) Take them back first to those cases in which they were judging those same things correctly, and having led them back, put those beside (para) the ones that aren't yet recognized, and by comparing (paraballontas) them show (endeiknunai) the same likeness and nature (tēn autēn homoiotêta kai phusin) which is in both combinations (sumplokais), until the things judged truly have been shown set beside (paratithemena deichthei i) all the ones not known. Once the things have been show (deichthenta), and thus

\footnotetext{
13 This opening section, 277d1-7 (with 278e4-11, which mentions waking up from our dreaming state by means of a model), has been taken to refer to Plato's doctrine of recollection (e.g., Shorey [1903], 43-44; Cherniss [1944], 47 n. 36; Goldschmidt [1947], 53-54; Robinson [1953], 214). See n. 2 above. Recollection is not explicitly mentioned in the Statesman, and the Stranger's account of learning and his method of teaching do not appear to rely on it.
} 
become models (paradeigmata), they cause each of all the letters in all the syllables to be called on the one hand "different," because it is different from 278C the others, and on the other hand "the same," because it is always invariably the same as itself.

Young Socrates: Absolutely.

Stranger: (3) Well then, have we grasped this adequately, that there is at that time the generation of a model, when the same thing, which is in something different and separated, is judged correctly, and having been brought together [with the first] results in one true judgment (mian alēthe doxan) about each and both?

Young Socrates: Apparently.

Stranger: (4) Then would we be surprised if our soul, having by nature experienced this same thing about the letters/elements (stoicheia) of everything, at one time is settled by truth about each one in some [complexes], whereas at another time again is all at sea about all of them in others, and somehow or other judges the constituents of the compounds themselves correctly, but again when they are transposed into the long and difficult syllables/complexes (sullabas) of things it fails to know those same things?

This passage appears to make the following claims: First, children learn their letters in simple syllables and are able to identify them correctly in those contexts, but when they see the same letters in longer complexes, they often make mistakes. Second, to teach the children to recognize the letters in the longer complexes, we set the short syllable, where the letter is correctly judged, beside (para) the long complex, where the letter is incorrectly judged. By setting the short syllable and long complex side-by-side ${ }^{14}$ the children come to recognize (are shown) that a certain letter is both the same and different in the two cases. Third, a model (paradeigma) is generated, when something is correctly judged as the same in a distinct and separate context. At this stage the children judge correctly both the example and the target, and make one correct judgment about each separately and both together. Finally, the Stranger generalizes: the experience of children learning their letters is true of all of us learning anything.

The Stranger's model of a model is underdetermined. The most straightforward interpretation makes it a model of the upcoming model of the statesman - that is, a model of the model of weaving, which will be differentiated from the kindred arts. In the model of weaving, we, like the children, recognize the essence of weaving, combining warp and weft, in relation to the various kindred and subsidiary arts, such as carding and spinning. This is the model we bring to the project of defining the statesman. Here we are all at sea,

${ }^{14}$ What Aryeh Kosman $(2005, \S 3)$ calls a "lateral comparison.” Kosman gives a helpful discussion of this passage, calling attention to Plato's use of the words para and deiknunai in his account of a model of a model. 
having only a general conception of the statesman as one who tends the human flock. Our task, as in the model of weaving, is to clarify our target by recognizing the essence of statecraft as distinct from the contributory and other subsidiary arts. Then we will grasp our target clearly both as what it is in itself and as different from the kindred arts with which it was initially confused.

The passage admits a second interpretation, which gives it more generality, allowing it to be a model for any successful model (excluding the myth, which the Stranger has already rejected as an inadequate model). We need to focus on stage (2) of our passage. What does the Stranger mean when he says that each of the letters in all the complexes is called on the one hand "different," because it is different from the others, and on the other hand "the same," because it is always invariably the same as itself(278b6-c1)? On my first interpretation, which looked ahead to weaving as a model for statecraft, I took the sample letter to stand for the similar content in the example and the target, namely, a certain internal structure (presumably intertwining [sumploke $]$, since that is common to both). This common element, which determines both weaving and statecraft, is in both cases to be marked off as different from the surrounding arts.

But there is a second interpretation, which I prefer. This second interpretation allows our model of a model to show what it is to be a model (both angling as a model for sophistry and weaving as a model for statecraft). On this interpretation, there is something the same in the example and the target, but whatever that is can also be called different, because it is related to different things in the two situations. To use terminology from the Sophist (255c14-15), the item modeled is in itself (kath hauto) the same in the example and the target, but in relation to other things (pros alla) it is different in the two situations.

Consider the Stranger's example of learning letters. A child knows the letter A in the word "cat." But he is confused about that very same letter in a complex word, say "asymmetric." The child is confused because the letter is combined with different letters in the two words. In "cat" the letter A connects two consonants. In "asymmetric," it is a negative prefix. The child's grasp of the letter A in the original example becomes useful only once he can abstract it from that context and recognize both that it is the same letter and that it operates differently in combination with different letters in the new situation.

The Stranger's model of a model concerns learning letters. Letters have content and no structure. On the interpretation I am advocating a letter in his example represents whatever one wants to model in the target, and sometimes that is some content-neutral structure, which is differently embodied in the example and the target. Consider a simple model in the Theaetetus. ${ }^{15}$ In his first attempt to define knowledge, Theaetetus gives a list: Knowledge is what Theodorus teaches - subjects like geometry-and crafts like cobbling $(146 \mathrm{c} 7-\mathrm{d} 3)$. Socrates objects that that is not what he is looking for in a definition. He wants to know what it is that makes the items on the list all instances of knowledge. He then offers a model definition of clay: "Clay is earth mixed with liquid" (147c4-6). This is a good model, involving a mundane, depictable example and exhibiting a structure discovered by a certain procedure. The structure is a combination of elements. That

\footnotetext{
${ }^{15}$ I call it a model. Plato's Socrates does not.
} 
structure can be discovered by a physical analysis of clay. This model is supposed to help Theaetetus define knowledge, about which he is all at sea. He should be looking for a similar structure in the target. But he should also recognize that it is one thing to define a material stuff as physical components mixed together, and something quite else to define an abstract concept like knowledge as conceptual components somehow combined. The Theaetetus enumerates and analyzes the components - perception, true judgment, and an account. The definition of clay suggests that Theaetetus' job is to figure out how the components fit together. But obviously, the structure revealed by the model will be differently realized in the target. That is what I mean when I say that one must recognize the difference between the structure as embodied in the example and in the target.

On this interpretation, the model of a model tells us something about the model of angling, as well as the model of weaving. The model of angling reveals a structure- the definition that results from a dichotomous division (summarized at 221a7-c3: the definition simply recounts the steps of the division). This definitional structure and the procedure that yields it should help Theaetetus and the visitor define the sophist. But there is an important difference between the structure and procedure involved in the simple example of angling and the difficult case of sophistry, as we shall see in Section 4. If I am right, the Stranger's model of a model shows us both how any good model should operate and alerts us to the dangers of over-dependence on the particular example that serves as the model. Models fall short: the relevant procedure is sufficient to yield the essence of the example, but it does not take us all the way to the essence of the target.

With this interpretation in mind, let us look again at our two helpful models, the model of angling and the model of weaving.

\section{Angling and Sophistry}

Our initial analysis of the angler overlooked a crucial point, the difference between the angler and the target the model was introduced to clarify. If the model is to be useful, it is as important to recognize that difference as it is to recognize the similarity.

The issue is first displayed in a dramatic detail. Before the investigation into the sophist, statesman, and philosopher begins, Socrates asks the guest whether he would prefer to go through his presentation in a long speech or through question and answer, the way Parmenides did with him, when Parmenides was very old and he was very young (217c1-7). Here Plato invites us to think of his dialogue Parmenides. The Stranger replies as follows - his words themselves recall a central issue in the second part of the Parmenides and prefigure an important distinction later in the Sophist (255c14-15):

If the answerer is untroublesome and manageable, it is easier [to show] him in this way, by speaking to him (to pros allon); otherwise, by oneself (to kath hauton). $(217 \mathrm{~d} 1-3)$

In this dramatic moment, talking about the manner in which the discussion will proceed, the Stranger introduces what will turn out to be a central issue for both the Sophist and the 
Statesman, but in different ways. To define something, we must recognize what that thing is in itself (kath hauto), but that recognition may be helped or hindered by various sorts of relativity (pros alla). The Statesman, relying on the model of weaving, marks off statecraft in relation to the contributory and other kindred arts and thus helps us isolate the statesman. The Sophist is particularly interested in a different sort of relativity, the various ways in which an entity appears to different observers, and how those various appearances can help or mislead us. The Stranger calls attention to this sort of relativity in his description of two sorts of presentation. In phrasing his statement as he does, saying that he will speak to Theaetetus (to pros allon), he indicates that Theaetetus' own conceptions will figure in the upcoming discussion, and not merely his own.

At the opening of the investigation into the sophist, to which the visitor soon turns, he cautions Theaetetus that the two of them may have only the name "sophist" in common, but perhaps they mean different things by the name (218b6-c3). They need more than mere agreement about the name. They also need to agree about the thing itself (to pragma auto) through its definition (logos) (218c4-5). Since it is so difficult to hunt down the sophist, the guest proposes that they practice on a small and easy case. He then defines the angler using the method of dichotomous division.

But an angler differs from a sophist in two significant respects. First, the essence of the angler is evident from his observable activity and is easy to spell out using dichotomous division. The Stranger and Theaetetus agree about the object, as well as the name (218e3-5; 221a7-b2). The essence of the sophist might also seem recognizable from his observable activities, but in fact it is not. The Stranger goes through seven divisions of the sophist. The first five specify some feature of the sophist's activity that enables one to pick out a sophist, but none of those divisions captures his essence: he's a hired hunter of rich young men; he's a wholesaler or retailer of his own intellectual wares or those of other people; he's an expert in the money-making branch of the art of disputation, and so on.

Once we finally uncover the essence of a sophist on the seventh round, we see that the first five divisions specified him by accidental features or by some feature that follows from his essence. They failed to specify what it is that makes someone a sophist (as opposed, say, to a lyric poet or a speech writer) and what it is about his activity that makes him so seductive and dangerous. Division of the sophist repeatedly misses the essence of the target until the Stranger collects the first six definitions (231d2-c6), and then observes that the appearance of manifold expertise is somehow unsound (232a1-6). ${ }^{16}$ The problem lies with us and our experience. We are missing that feature of the sophist that links the appearances together: his essence. Reliance on the model of the angler can thus mislead, if one thinks that dichotomous division guarantees a route to the essence. Division may simply reflect the inquirers' contingent experience.

Second, the nature of angling is uncontroversial. The Stranger and Theaetetus mean the same thing by the name. By contrast, people disagree about what sophistry is. ${ }^{17}$ In consequence they have different conceptions of the art, and some of those conceptions are

${ }^{16}$ On this passage, see the excellent discussion by Notomi (1999). See also Gill (2005) and (forthcoming).

${ }^{17}$ Cf. Phdr. 263a2-b2 on the difference between words like "iron" and "silver," on the one hand, and words like "just" and "good," on the other. There is an easy procedure to decide whether something is iron, but no obvious procedure to decide about disputed concepts, like justice or goodness. Cf. Euth. 7b6-d8. 
simply mistaken. Whereas the first five divisions locate sophistry somewhere under acquisitive art, the sixth division (226b1-231b8), which isolates the so-called "noble" art of sophistry, locates it in a quite different place, under the art of separation, which was not even marked off in the original dichotomous division of art. The individual who practices this art purifies souls of beliefs that interfere with learning. The noble sophist looks a lot like Socrates. This division calls attention to the fact that many people mistook Socrates for a sophist. ${ }^{18}$ The sixth definition does not reveal even an accidental feature of a sophist. Instead it captures a distinct kind, which shares with the sophist only the name in common owing to a superficial resemblance. ${ }^{19}$

The model of angling shows how the method of division is supposed to work and the structure the definition of the target is supposed to display. The example also guides the first five divisions, which find the sophist at the ends of various branches that stem from acquisitive art. The final, seventh division, starts instead from a branch marked off and abandoned at the outset in the search for the angler, and locates the sophist's activity under productive art (265a4-b2). The sophist is ultimately defined as someone who produces false appearances. Even the first step in the division of the angler is rejected in the end. The model of the angler shows how to start the investigation, and it helps to clarify the correct procedure and the structure of the final definition. But as an example it takes the inquirers in the wrong direction.

At the beginning of the Statesman, Plato uses the drama to reveal a point to which I have called attention in the Sophist. The Eleatic visitor proposes to substitute Theaetetus with his partner in training, Young Socrates, and to undertake the next investigation with him. Theodorus approves the idea, saying that each of them will perform better if they take a rest. Socrates (the elder) adds:

Furthermore, both of them look like they somehow have a certain kinship (sungeneian) with me. For you say the one appears similar (homoion) to me in the nature of his face; but the name and form of address of the other one, since it is the same as mine (homōnumos), provides a certain relatedness (oikeiotêta). Indeed, we must always be ready to recognize our kin through talking to them (dia logōn). (257d1-258a3)

This passage captures in a dramatic nutshell a central issue in the Sophist. Suppose your target is Socrates. You can be misled by Theaetetus' facial resemblance into thinking he is Socrates. Or you can be misled by the fact that Young Socrates shares his name into thinking he is the famous Socrates. ${ }^{20}$ It is only by getting clear about each of the three and

\footnotetext{
${ }^{18}$ Aristophanes' Clouds parodied Socrates as a sophist. In his defense at his trial in Plato's Apology Socrates recognizes that many people associated him with the sophists and takes some trouble to distance himself from them, especially on the matter of charging fees.

${ }^{19}$ Compare the Phaedrus. The first part of that dialogue discusses two quite different things called "love"one characterized as a human sickness, the other as divine inspiration. In the second part of the dialogue, Socrates locates both under a higher kind: madness (265e1-266b1). Though both are called "love," they are two distinct kinds.

${ }^{20}$ On this passage, see Miller (1980), 5-8; cf. Rosen (1983), 21.
} 
how they are really related to each other that we can be sure we have got our target. And that is the main task of the Statesman.

\section{Weaving and Statecraft}

The model of weaving reveals that statecraft must be defined in relation to the kindred arts. It also reveals something about the essence of the statesman's activity: he weaves together all aspects of things in the city, and in particular he weaves together the virtues of courage and moderation, which are often in conflict. Furthermore, the weaver and the statesman are both experts in measurement: they measure the more and the less not only in relation to each other but also in relation to the production of the measure. We are not told much about the measure, but the measure appears to be the good to be achieved in their respective arts (284a5-e8). ${ }^{21}$ Furthermore, both the weaver and the statesman are said to direct the subsidiary experts, whose products and activities they use (305a1-6, 308d1e2). The statesman directs the experts who are, as it were, the practical arms of his expertise: the orator, the general, the judge, and the teacher. The statesman must be an expert in timing to determine when the general should go to war, though he leaves it to the general to work out the details of military strategy and to carry them out. ${ }^{22}$ He must determine the good that rhetoric will serve, though he leaves the techniques of persuasion and its practice to the rhetorician. The statesman must decide whether a particular goal is best achieved through force or persuasion, or through force with some people, persuasion with others, and then delegate the tasks to the appropriate experts. The statesman must also decide what is just and lawful, though he leaves it to the judges to implement his judgment. The statesman must further decide what mix of courage and moderation will most advance the good in the city, though he leaves it to the teachers to instill in the youth the right belief about what is good (308e4-310a5). The visitor tells us that the statesman cares for every aspect of things in the city, weaving them together in the most correct way (305e2-6).

Division by limbs suffices to isolate the essence of weaving from the contributory and other subordinate arts that operate in the same domain. But this method, while taking us most of the distance, does not take us all the way to our target, the statesman. Missing from the model is the idea conveyed by the original paradeigma of the herdsman who tends his flock. Contrary to what some scholars have claimed, the Stranger does not abandon the original conception of the statesman as a herdsman of the human flock. ${ }^{23}$

\footnotetext{
21 On the two arts of measurement, see esp. Sayre (2007).

22 See Lane (1998) on the significance of timing in the statesman's art.

${ }^{23}$ For the continued use of the imagery of herding, see, e.g. 294e8-295a1, 295e4-296a2, and for evidence that we are continuing the original division, see 292b12-c3. On this point I agree with Weiss (1995) and El Murr (2005), against e.g. Owen (1973), 352, and Lane (1998), 43-46. Rowe (1996), 162 n.23 and 163 n.25, speaks of the demise of the idea of the king as herdsman and cites as an example 276a-b. But this passage appears to me to reassert the idea, though with "care" in place of "rearing/nurture." Perhaps scholars think the definition of the statesman as herdsman must be rejected, because only one paradeigma can capture the essence of the target. But if I am right, different models can be useful at different stages of the investigation of a single target. Consider the fact that the example of angling utterly fails to illuminate the essence of the sophist. That does not undermine the usefulness of the model in revealing the structure of a definition
} 
The model of the herdsman is itself ambiguous, as we know from Republic I. Does the herdsman/ruler rear his flock for the benefit of his flock or for the benefit of himself (Rep. I, 343b1-344c8)? Neither the example of weaving nor the example of herding adequately shows how to distinguish the true statesman, who tends his herd with knowledge of what is good for his herd, from his various imitators, who merely seem to possess the requisite knowledge (293c5-d2). To address this shortcoming, the Stranger introduces two analogies, which indicate how to distinguish experts from their imitators. These analogies are the doctor and the steersman. It makes no difference, says the visitor, whether the doctor cures us with or without our consent, according to written rules or without them, or as a rich man or poor man. All that matters is that he cares for our bodies for the good of our bodies, making them better than they were, and so preserving what is in his care (293b1-c3). Similarly the steersman cares for the good of his sailors and ship, and thus preserves them, not putting things in writing, but offering his expertise (techne $)$ as law (296e4-297a2). The distinguishing feature of the genuine statesman emerges from these comparisons. The Stranger says that the truest criterion (horos) of correct management of a city is that by which the wise and good man manages the affairs of the ruled, for their benefit, using the power of his expertise, which is stronger than the laws (296e1-4; 297a3b3).

The Stranger presents an image (schèma) of fake doctors and steersmen, who are not concerned to benefit those in their care (298a1-e3), and then characterizes the true doctor and steersman as perceived by those who don't know (299b2-e5). Whereas the first lot will be called "doctors" and "steersmen," though in fact they are not, a true practitioner will be called a "stargazer" (meteōrologon) and "babbling sophist" (adoleschèn tina sophistèn) (299b6-8). ${ }^{24}$ These analogies show that unless we are careful in our divisions, we will include the imitators among the genuine experts and mistake true expertise for sophistry (recall the noble art of sophistry in the Sophist). The analogies of the doctor and the steersman guide the differentiation of the true statesman from his imitators - the rulers of the various degenerate states. Unlike other rivals, who can be said to care for the human flock, these imitators merely appear to do so. They lack knowledge (epistēmē) and so should be excluded from the whole division that leads to the statesman. ${ }^{25}$ They are, in fact, appearances of the sophist. The visitor calls them the greatest sophists of all (303c4-5).

I have resisted calling the doctor and the steersman "models," because Plato does not call either of them a "paradeigma." Even so, they appear to function as models. The distinguishing mark of both sorts of expert helps to reveal the distinguishing mark of the genuine statesman: they aim to benefit those in their care. Furthermore, we isolate their essence by differentiating them from their imitators - people who share with them a

reached by dichotomous division, a model relevant for the statesman as well as the sophist. Cf. Kato (1995), 165.

${ }^{24}$ Cf. Phdr. 269e4-270d8, where Socrates says that all the greatest arts need adoleschias kai meteōrologias about nature. These terms were used pejoratively of genuine expertise by people like Aristophanes (Clouds 228,1480 ). Our passage in the Statesman (cf. Rep. IV, 488d4-489a2) suggests that Plato tends to use the terms for genuine experts whose expertise is not recognized by the populace. I discuss this topic in more detail in Gill (2003b), n. 32.

${ }^{25}$ There is some disagreement about whether they are excluded or not. On this point I side with Miller (1992), 342 n. 42, 348 n. 29. 
superficial resemblance and go by the same name but possess a quite different skill. So discussion of the doctor and steersman indicates a procedure that will help us define the statesman as well. They particularly help us to see what differentiae are not relevant to his essence, such as rule with or without laws, rule by one, few or many, rule with or without the consent of the ruled (these differentiae distinguish the degenerate rulers from one another).

These two models fall short, too, because they do not reveal what the statesman's knowledge is or how it relates to the arts most akin to his - those of the orator, general, judge, and teacher (303e7-305e6). ${ }^{26}$ The Stranger starts this final differentiation by appeal to yet another little model: refining gold (separate it first from the dross, then from the other precious metals) (303d9-304a4). He then returns to the model of weaving. Like the weaver, who prescribes what he needs to those who prepare his materials, and directs their preparation, so the statesman prescribes to his closest subordinates what he aims to achieve and directs them to execute his orders (308d1-e2). In this final part of the dialogue, which relies on division by limbs, the statesman is separated off from others who work in the same domain and he is defined in relation to them, as the one who controls and coordinates their various activities.

The Statesman presents a single complex division, which progressively sharpens our logos of the statesman. ${ }^{27}$ We have talked about many models. I have argued that each is relevant at some stage of the inquiry: angling (from the previous dialogue) reveals the original definitional procedure, dichotomous division; weaving shows how to mark off the statesman from other kindred experts who operate in the same domain; medicine and navigation show how to distinguish the statesman from his imitators; and refining gold shows how to mark off the statesman in relation to his closest and most precious kin. The herdsman, though introducing no new procedure, influences the overall direction of the division. None of these models can or should guide the investigation the whole way. After all, a model is supposed to be simple and easy to grasp, whereas the target is great and difficult. $^{28}$

Mary Louise GILL Brown University

\footnotetext{
${ }^{26}$ Many scholars mention only the first three sorts of experts as the statesman's closest kin, because only they are explicitly listed at 303e7-304a6. But the partitive genitive toutōn at 303e10 leaves it open that other sorts of experts may belong to that group, and the Stranger turns immediately to the role of the teacher (304a6-c6) before discussing the rhetorician, general, and judge.

27 I share this view with Dimitri El Murr (2005), though I believe we differ on the status of division by limbs. I take division by limbs to differ significantly from dichotomous division, whereas he appears to think that it can be displayed dichotomously.

${ }^{28}$ I gave earlier versions of this paper at a conference on Plato's Statesman at the University of Notre Dame and at a conference, "Being, Nature, and Life," in honor of Allan Gotthelf, at the University of Pittsburgh. I am very grateful to the participants on both occasions for their stimulating questions and suggestions, and especially to Dimitri El Murr for his challenging comments at Notre Dame.
} 
M. L. Gill 15 of 16

\section{BIBLIOGRAPHY}

Burnyeat, M. F. 1997. "First Words." Proceedings of the Cambridge Philological Society 43: $1-20$.

Cherniss, H. 1944. Aristotle's Criticism of Plato and the Academy. Baltimore: The Johns Hopkins Press.

Dorter, K. 1994. Form and Good in Plato's Eleatic Dialogues. Berkeley, CA: University of California Press.

El Murr, D. 2005. "La division et l'unité du Politique de Platon.” Les études philosophiques 3: 295-324.

. 2006. "Paradigm and diairesis." Journal of the International Plato Society, 6.

Gill, M. L. 2003a. "Why Does Theaetetus' Final Definition of Knowledge Fail?" in W. Detel, A. Becker, and P. Scholz (eds.), Ideal and Culture of Knowledge in Plato. Stuttgart: Franz Steiner Verlag. 159-73. . 2003b. "Plato's Phaedrus and the Method of Hippocrates." The Modern Schoolman 80: 295-314. . 2005. "Method and Metaphysics in Plato's Sophist and Statesman." The Stanford Encyclopedia of Philosophy, Edward N. Zalta (ed.), URL = http://plato.stanford.edu/entries/plato-sophstate/

. Forthcoming. "Division and Definition in Plato's Sophist and Statesman." In D. Charles (ed.), Definition in Greek Philosophy. Oxford: Clarendon Press.

Goldschmidt, V. 1947. Le Paradigme et la dialectique platonicienne. Paris: Presses Universitaires de France.

Kato, S. 1995. "The Role of Paradeigma in the Statesman." In C. Rowe (ed.), Reading the Statesman. Sankt Augustin: Academia Verlag. 162-72.

Kosman, L. A. 2005. "The Faces of Justice: Difference and Equality in Plato's Republic." Boston Area Colloquium in Ancient Philosophy 20.

Lane, M. S. 1998. Method and Politics in Plato's 'Statesman'. Cambridge: Cambridge University Press.

Miller, M. H. 1980. The Philosopher in Plato's 'Statesman'. The Hague: Nijhoff. 323-59. . 1992. "The God-Given Way." Proceedings of the Boston Area Colloquium 6: 
Notomi, N. 1999. The Unity of Plato's 'Sophist'. Cambridge: Cambridge University Press.

Owen, G. E. L. 1973. "Plato on the Undepictable." In E. N. Lee, A.P.D. Mourelatos, R. M. Rorty (eds.), Exegesis and Argument (= Phronesis Suppl. 1). New York, N. Y.: Humanities Press. 349-61. Repr. in G. E. L. Owen, Logic, Science, and Dialectic: Collected papers in Greek Philosophy. M.C. Nussbaum (ed.). London: Duckworth and Ithaca, NY: Cornell University Press, 1986.

Robinson, R. 1953. Plato's Earlier Dialectic. $2^{\text {nd }}$ edn. Oxford: Clarendon Press.

Rosen, S. 1995. Plato's Statesman: The Web of Politics. New Haven, Conn.: Yale University Press.

Rowe, C. J. 1995a. Plato: Statesman. Warminster: Aris \& Phillips. . (ed.) 1995b. Reading the Statesman. Sankt Augustin: Academia Verlag. . 1996. "The Politicus: Form and Structure." In C. Gill and M. M. McCabe (eds.), Form and Argument in Late Plato. Oxford: Clarendon Press.

Sayre, K. 1992. "A Maieutic View of Five Late Dialogues." In J. C. Klagge and N. D. Smith (eds.), Methods of Interpreting Plato and his Dialogues (= Oxford Studies in Ancient Philosophy. Suppl.). 221-43. University Press. 2007. Method and Metaphysics in Plato's Statesman. Cambridge: Cambridge

Shorey, P. 1903. The Unity of Plato's Thought. Chicago: The University of Chicago.

Weiss, R. 1995. "Statesman as epistēmōn: Caretaker, Physician, and Weaver," in C. J. Rowe (ed.), Reading the Statesman. Sankt Augustin: Academia Verlag. 213-22. 